\title{
IMPROVING MATHEMATICAL COMMUNICATION CAPABILITIES BY REALISTIC MATHEMATICS APPROACH
}

\author{
Juliati $^{1}$, Muhammad Firman ${ }^{2}$, Derry Nugraha ${ }^{3}$ \\ ${ }^{1.2}$ STKIP PGRI, Sukabumi \\ ${ }^{3}$ IKIP Siliwangi, Bandung \\ ${ }^{1}$ juliati@ stkippgrisukabumi.ac.id, ${ }^{2}$ firmanimani@gmail.com, ${ }^{3}$ n14d75@ yahoo.com
}

Received: Sep 29 ${ }^{\text {th }}$, 2018; Accepted: Oct $1^{\text {st }}, 2018$

\begin{abstract}
The background of this study is the lack of mathematical communication skills (MCS) of junior high school students in Cimahi. This study aims to examine the achievement and improvement of MCS of junior high school students in Cimahi by realistic mathematical approaches. This study involved two groups, namely the experimental group and the control group. All groups were given a pretest and posttest. The experimental group obtained mathematics learning with realistic mathematical approaches as treatment and control groups obtained mathematics learning as usual as a treatment. This research method is an experimental research with pretest-posttest control group design, namely the design of the pretest posttest control group that involves two groups and randomly sampled classes. The population were junior high school students in Cimahi, while the sample consisted of two randomly selected classes. Obtained class VIII M (experimental class) and class VIII K control class. The instrument was a 5-item MCS description test, then the skills scores MCS students' were analyzed with descriptive and inferential statistics using assistance Minitab 17. Based on the results of the study, it was concluded that the achievement and improvement of students' MCS using mathematical realistic approaches were better than students who used ordinary learning.
\end{abstract}

Keywords: communication, realistics mathematical approaches

\begin{abstract}
Abstrak
Latar belakang penelitian ini adalah masih kurangnya kemampuan komunikasi matematik siswa SMP di Cimahi. Penelitian ini bertujuan untuk menelaah pencapaian dan peningkatan kemampuan komunikasi matematik siswa SMP di Cimahi antara yang pembelajarannya dengan pendekatan matematika realistik. Penelitian ini melibatkan dua kelompok, yaitu kelompok eksperimen dan kelompok kontrol. Semua kelompok diberi pretes dan postes. Kelompok eksperimen memperoleh pembelajaran matematika dengan pendekatan matematika realistik sebagai perlakuan dan kelompok kontrol memperoleh pembelajaran matematika seperti biasa sebagai perlakuan. Metode penelitian ini adalah penelitian eksperimen dengan penelitian dalam bentuk pretest-posttest Control Group Design, yaitu desain kelompok kontrol pretes postes yang melibatkan dua kelompok dan pengambilan sampel dilakukan secara acak kelas. Populasi dalam penelitian ini adalah siswa SMP di Cimahi, sedangkan sampelnya terdiri dari dua kelas yang dipilih secara acak. Diperoleh kelas VIII M (kelas eksperimen) dan kelas VIII K kelas kontrol. Instrumen yang digunakan adalah bentuk tes uraian kemampuan komunikasi matematik sebanyak 5 soal, kemudian data skor kemampuan komunikasi matematik siswa tersebut dianalisis dengan statistik deskriptif dan inferensial menggunakan bantuan Minitab 17. Berdasarkan hasil penelitian, disimpulkan bahwa pencapaian dan peningkatan kemampuan komunikasi matematik siswa yang menggunakan pendekatan realistik matematik lebih baik dari siswa yang menggunakan pembelajaran biasa.
\end{abstract}

Kata Kunci: komunikasi, pendekatan matematika realistik 
How to Cite: Juliati, Firman, M., \& Nugraha, D. (2018). Impoving Mathematical Communication Capabilities by Realistics Mathematics Approach. JIML, 1 (3), 338-344.

\section{INTRODUCTION}

Ruseffendi (2010) said, Mathematics arises because of human thoughts, which are related to ideas, processes and reasoning. Mathematics is the science (mathematics is the queen of the sciences), meaning that mathematics does not depend on other fields of study: the knowledge of the pattern of order, and the science of organized structures. NCTM (2000) recommends five main core competencies of mathematics, (1) The ability of problem solving, (2) communication skills, (3) The ability of the connection, (4) The ability of reasoning, (5) the ability of representation.

In a research, Merdian, Sari, \& Sugandi (2018) described the low ability of MCS. They found that students had lack of spirit and low enganging in learning. It caused the low ability of MCS in high school students. Based on the description, one of the objectives to be achieved in mathematics learning is the ability of students in mathematical communication, because MCS are one of the standard processes in mathematics learning in schools. Chotimah (2015) revealed that, through mathematical communication, students can organize and consolidate their mathematical thinking both verbally and in writing, while renegotiating responses between students will occur in the learning process. In the end it will bring students to a deep understanding of the mathematical concepts learned.

The importance of mathematical communication according to Baroody (1993), because mathematics is an essential language that is not only a means of thinking, finding formulas, solving problems or concluding clearly, accurately and precisely, and mathematics and learning mathematics is the heart of students, among students and teacher, between the material of mathematics lessons, interaction between teachers and important factors in advancing the potential of students.

Many factors cause students to lack MCS, one of which is that teachers emphasize more on the teacher center rather than student center. Through teacher-centered learning, the teacher only explained the material, more to the lecture method, while the students only listened to what was said by the teacher so that students were less active in learning activities. The activeness of students during learning is very necessary, as stated by Ruseffendi (2006) that learning and / or working actively is more fun, that active learning will broaden horizons. So that other factors that cause students' low MCS are inappropriate approaches, methods, strategies and learning models. Therefore the teacher must choose appropriate and appropriate approaches, methods, strategies and learning models, so as to make students active and learn more meaningful. Suherman (2008) said that teachers should choose and use strategies, approaches, methods, and techniques that can actively involve students in the learning process.

Based on the description above, researchers try to apply a learning approach that emphasizes students as a learning center (student center) and as a means to improve students' MCS, namely learning with a realistic mathematics approach (PMR). PMR views that mathematics as a human activity. Learning must be active both mentally and physically in learning mathematics. In addition, this approach can be used because the learning is related to everyday life or can be imagined by students, so students will not forget quickly, learning is more interactive, creative, brave to express opinions, but it will also grow and increase knowledge through experience, his discovery and knowledge, and can make the teaching process more enjoyable. Freudenthal (1987) revealed that mathematics is a human activity and 
must be linked to reality. Based on these thoughts Gravemeijer (1999), realistic mathematics has characteristics, among others, that in the learning process students must be given the opportunity to rediscover (to reinvent) mathematics through teacher guidance.

\section{METHOD}

This study involved two groups, namely the experimental group and the control group. All groups were given a pretest and posttest. The experimental group obtained mathematics learning with realistic mathematical approaches as treatment and control groups obtained mathematics learning as usual as a treatment. In addition, the independent variables are manipulated. So according to the method, this study is an experimental research with pretestposttest control group design, which is the design of the posttest pretest control group that involves two groups and randomly selected classes. The research design is described as follows Ruseffendi (2005):
A O X O
A $\mathrm{O} \quad \mathrm{O}$

Description A: Random sampling of classes.

O: $\quad$ Pretest $=$ posttest (MCS test).

$\mathrm{X}$ : Mathematical learning with realistic mathematical approaches.

The population in this study were all Public Middle Schools in Cimahi City whose characteristics had low MCS. The sample of the school was chosen randomly so that it was obtained SMP Negeri 3 Cimahi representing the characteristics of the population. Then in class VIII two classes were randomly selected to be used as experimental and control classes. Class VIII was chosen because it is a class that is in accordance with the mathematics learning material that will be studied. Then class VIII-M was chosen as the experimental class and class VIII-K as the control class.

\section{RESULTS AND DISCUSSION Results}

Table 1. Descriptive Statistics Pretest, Postes and Experiment Class Gain and Control Class

\begin{tabular}{llll}
\hline Data & & $\begin{array}{c}\text { Experiment } \\
(\mathrm{n}=36)\end{array}$ & $\begin{array}{c}\text { Control } \\
(\mathrm{n}=36)\end{array}$ \\
\hline Pretest & $\mathrm{x}$ & 5,833 & 5,167 \\
\hline & $\mathrm{S}$ & 1,844 & 1,797 \\
\hline Posttest & $\mathrm{x}$ & 12.33 & 10.53 \\
\hline & $\mathrm{S}$ & 3.389 & 3.865 \\
\hline N-Gain & $\mathrm{x}$ & 0,468 & 0,362 \\
\hline & $\mathrm{S}$ & 0,211 & 0,243 \\
\hline
\end{tabular}

Table 2. Statistical Test Results MCS

\begin{tabular}{|c|c|c|c|c|}
\hline \multirow[b]{2}{*}{ Class } & \multicolumn{4}{|l|}{ Significance } \\
\hline & Normality & $\begin{array}{l}\text { Test } \\
\text { Homogeneity }\end{array}$ & $\begin{array}{l}\text { Test } \\
\text { Difference } \\
\text { Test Two } \\
\text { Average }\end{array}$ & $\begin{array}{l}\text { Non- } \\
\text { parametric } \\
\text { Test (Mann } \\
\text { Whitney) }\end{array}$ \\
\hline
\end{tabular}




\begin{tabular}{|c|c|c|c|c|c|}
\hline & & & & averag & \\
\hline \multirow[t]{2}{*}{ Pretest } & Experiment & $>0,150$ & & & \multirow{2}{*}{0,146} \\
\hline & Control & 0,031 & & & \\
\hline \multirow{2}{*}{ Postes } & Experimental & $>0,150$ & \multirow{2}{*}{0,440} & \multirow{2}{*}{0,019} & \\
\hline & Control & $>0,150$ & & & \\
\hline \multirow{2}{*}{ N-Gain } & Experimental & $>0,150$ & \multirow{2}{*}{0,405} & \multirow{2}{*}{0,026} & \\
\hline & Control & $>0,150$ & & & \\
\hline
\end{tabular}

Based on data from research conducted by researchers for approximately one month or nine meetings in each class. The first meeting was used for pretest, so that the second meeting until the seventh meeting was used for learning with a predetermined treatment. In the experimental class given treatment with PMR and for the control class given treatment with ordinary learning. After carrying out the learning, the researcher gave a posture to see the achievement and improvement of students' MCS after being given the prescribed treatment from both classes.

From the data analysis carried out by the researcher, it was shown that the achievement and improvement of MCS of State Middle School students who learned to use PMR were significantly better than those who used ordinary learning. In learning with PMR, researchers informed that learning will be carried out using student worksheets (LKS) based on PMR through learning models cooperative learning. By learning in groups students will exchange opinions, exchange information, learning will be easier, and besides that the discussion is one aspect of communication as stated by Baroody (1993), Discussion is a means for someone to express and reflect on his thoughts related to the material taught.

In PMR learning students are required to be able to discuss real problem solving for students listed in the LKS, besides that students are motivated to develop or create symbolic models informally, students are given the freedom to solve problems in their own ways, and can be interactive with other students or with the teacher. The activity then presents the results of the discussion in front of the class, and reflects on each step taken or on the results of the lesson. The stages of PMR-based worksheets are as follows:

1. Learning begins with the involvement of students in understanding and completing the contextual issues contained in the LKS.

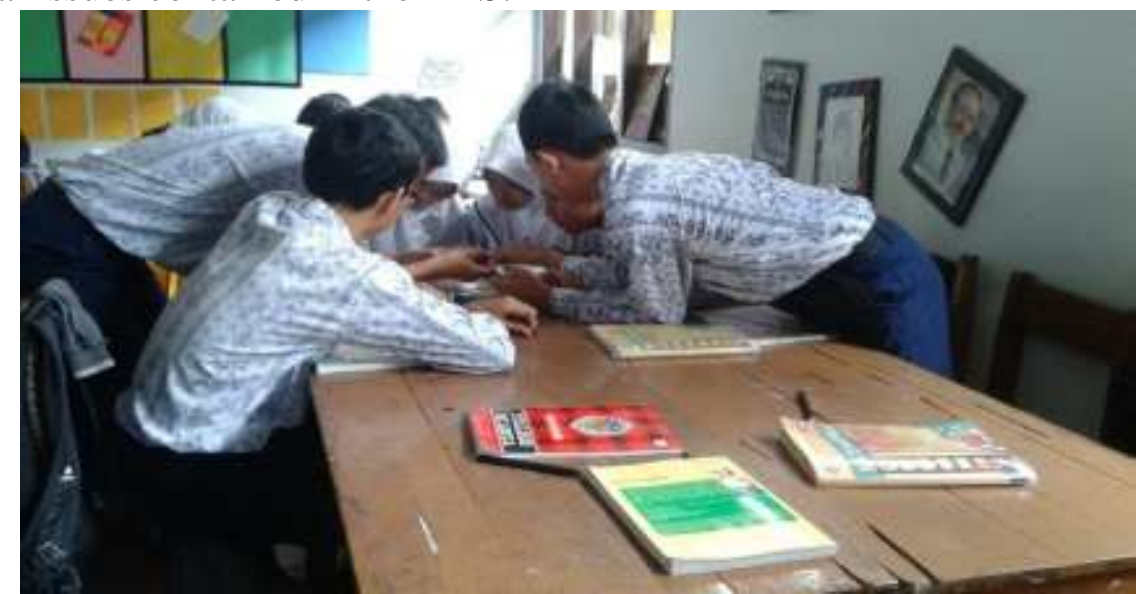

Figure 1. The Process of Observing, and Resolving, Contextual Problems Mathematical 
342 Juliati, Firman, \& Nugraha, Impoving Mathematical Communication Capabilities by Realistics Mathematics Approach

2. concepts or ideas are reconstructed by students through vertical instrument models, which move from informal procedures to formal forms.

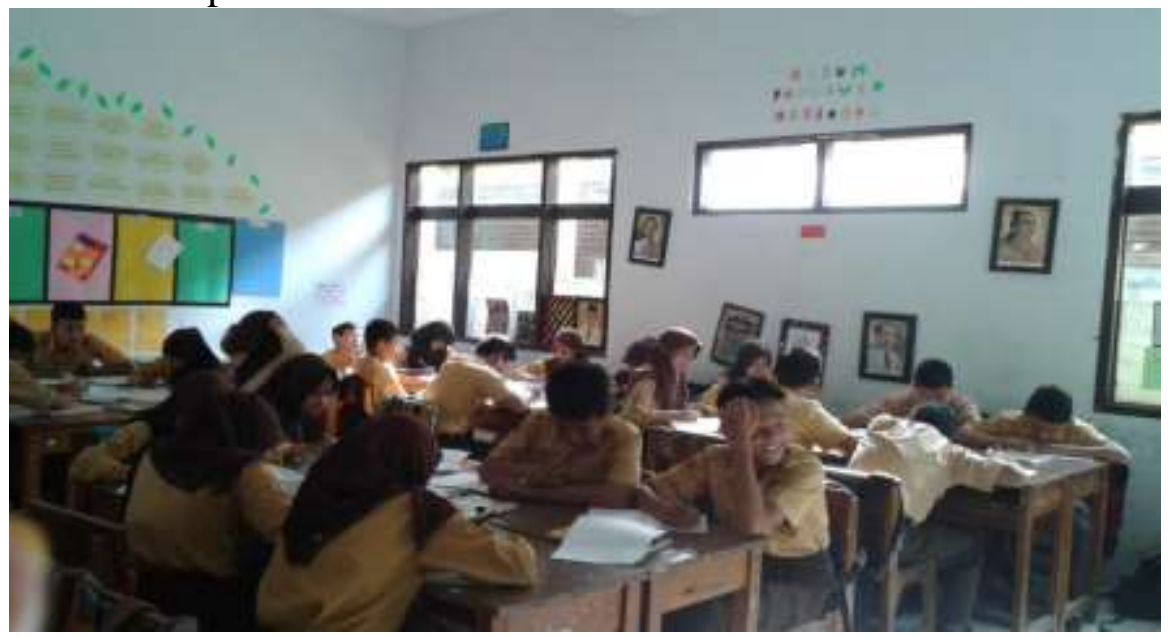

Figure 2. Process of Reconstruction and Contribution of Students

3. Students are asked to present the results of the work in front of the class.

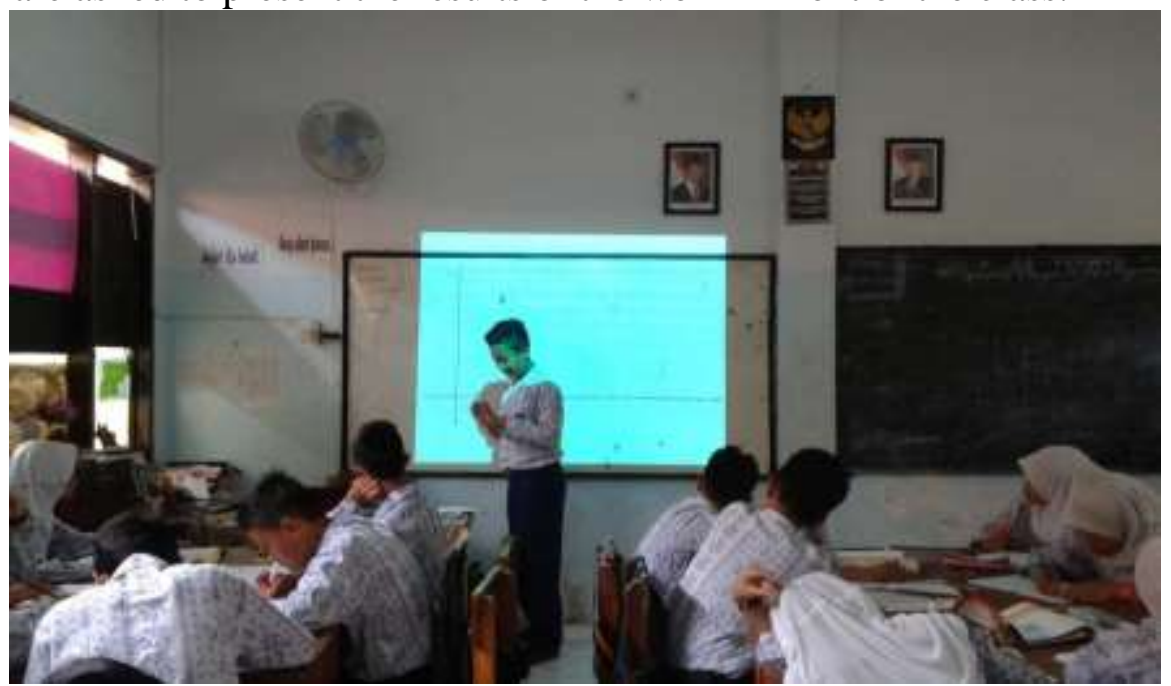

Figure 3. Each Representative Presenting the Answers Problem on LKS

4. Students are directed to draw conclusions about solving problems, concepts, procedures, or principles that have been built together. Then ended with an individual evaluation at the end of each lesson in the form of written exercises or question and answer. 


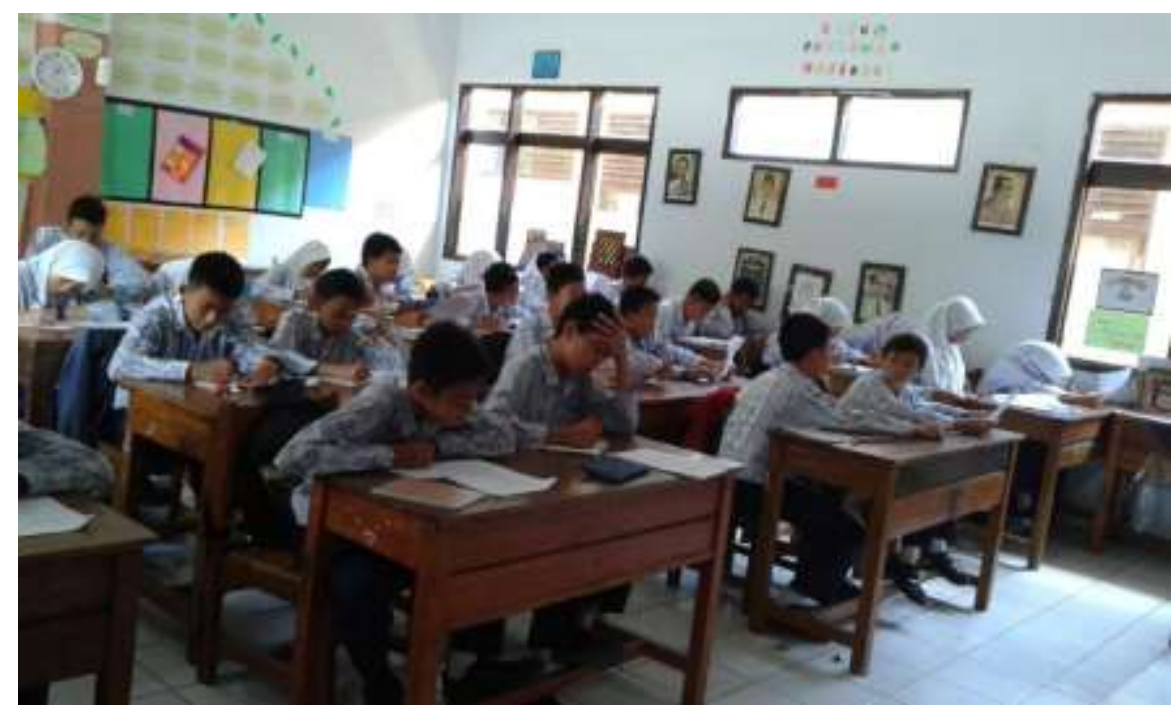

Figure 4. Interesting Conclusions and Evaluations

Based on the experience experienced by researchers during the research process, researchers found several advantages of using realistic mathematical approaches, including being able to provide clear understanding to students about the relationship between mathematics and everyday life and about the usefulness of mathematics in general. for humans, students become more active in expressing their opinions because learning is related to the real life of students, students are active in solving problems in their own ways, and with this approach students are not only easy to master the concepts and subject matter but also not quickly forget what they have obtained that.

This is also in line with the opinion of Kuiper \& Kuver (Chotimah, 2015), several preliminary studies in several countries show that learning to use PMR, mathematics is more interesting, relevant and meaningful, not too formal and not too abstract, considering the level of student ability, emphasizing mathematics learning with 'learning by doing', problem solving without using standardized solutions, and using context as the starting point of learning.

Besides that, the constraints experienced by researchers in the learning process have students who are less active when learning takes place, and during the discussion there are group members who only rely on smart themes who do not actively participate in discussions, but researchers try to overcome these obstacles by motivating students to play an active role when learning.

The results of the pretest on the two average difference test in Table 2 shows that there is no significant difference in the students' initial mathematical communication skills between those learning using realistic mathematical approaches and those using ordinary learning. After being given treatment for seven meetings then post-test. From the calculation of the twoaverage difference test in Table 2. shows that the achievement of mathematical communication skills of students who learn using realistic mathematical approaches are significantly better than those who use ordinary learning. This is due to several supporting factors including: research that is in accordance with procedures, students' ability to support, in the theoretical study the approach to realistic mathematics learning corresponds to indicators of mathematical communication skills, and processing all data in accordance with the accuracy of the analysis. After being explained in the next discussion, to see the increase, thedata processing is carried out gain normalized. Based on the results of the two average difference test in Table 2 shows that the improvement of students' MCS whose learning uses a realistic mathematical approach is significantly better than those using ordinary learning. 
Based on the observations of the researchers, there are several factors that lead to an increase in students' MCS whose learning uses a realistic mathematical approach better than those using ordinary learning, including:

1. The existence of worksheets that contain problems relevant to the day-to-day life so students can actively think. Giving LKS can help students connect the concepts they have with the concepts to be studied. In addition, students can develop MCS.

2. There is an activity or presentation stage in front of the class, at this stage can train students to express ideas and can increase students' self-confidence. In addition, at this stage students can play an active role in responding to class representatives who present the results of the discussion by asking questions, providing input or objections.

\section{CONCLUSION}

Based on the data analysis and discussion described in the previous chapter, the researchers concluded that the

1. achievement of mathematical communication skills of public junior high school students whose learning uses realistic mathematical approaches is better than those using ordinary learning.

2. Improved mathematical communication skills of state junior high school students whose learning uses a realistic mathematical approach better than those who use ordinary learning.

\section{Suggestion}

Based on the research results and conclusions obtained, the researcher revealed several suggestions that might be used as a reference and reflection for some parties, namely a realistic mathematical approach can be implemented at the elementary / equivalent level, and SMP / equivalent. Realistic mathematics approach is not appropriate if implemented at the high school / equivalent level because it will prevent students from thinking abstractly.

\section{REFERENCES}

Baroody, A. J. (1993). Problem Solving, Reasoning \& Communicating, K-8: Helping Children Think Mathematically. Newyork: McMillan Publishing Company.

Chotimah, S. (2015). Upaya Meningkatkan Kemampuan Komunikasi Matematik Siswa SMP di Kota Bandung dengan Pendekatan Realistic Mathematics Educations pada Siswa SMP di Kota Bandung. Didaktik, 9(1), 26-32.

Freudenthal, H. (1987). Mathematics Starting and Staying in Reality. Proceedings of the USCMP Conference on Mathematics Education on Development in School Mathematics around the World, NCTM, Reston, VA.

Gravemeijer, K. (1999). Context Problems in Realistic Mathematics Education: A Calculus Course as An Example. Educational Studies in Mathematics, 39(1-3), 111-129.

Merdian, A., Sari, V.T.A., Sugandi, A. I. (2018). Analisis Kemampuan Komunikasi Matematis dan Keaktifan Siswa SMA dengan Pendekatan Problem Posing. Sosiohumaniora: Jurnal Ilmiah Pendidikan Ilmu Sosial Dan Humaniora, 4(1).

NCTM. (2000). Principles and Standards for School Mathematics. USA: NCTM.

Ruseffendi, H. E. T. (2005). Dasar-Dasar Penelitian Pendidikan dan Bidang Non- Eksakta Lainnya. Bandung: Tarsito.

Ruseffendi, H. E. T. (2006). Pengantar kepada Membantu Guru Mengembangkan Kompetensinya Dalam Pengajaran Matematika.

Ruseffendi, H. E. T. (2010). Dasar-dasar Penelitian Pendidikan dan Bidang Non Eksakta Lainnya. Bandung: Tarsito.

Suherman, E. (2008). Belajar dan Pembelajaran Matematika. Bandung: Tidak Diterbitkan. 